\title{
母相より硬い析出物を生成する相分解過程の 計算機シミュレーション†
}

\author{
池 田 英 幸* 松田日出彦**
}

*鹿児島工業高等専門学校機械工学科

**九州工業大学工学部物質工学科

J. Japan Inst. Metals, Vol. 59, No. 7 (1995), pp. 694-702

\section{Computer Simulation of Phase Decomposition Process Generating Precipitates Harder than Matrix}

\author{
Hideyuki Ikeda* and Hidehiko Matsuda** \\ *Department of Mechanical Engineering, Kagoshima National College of Technology, Kagoshima \\ ** Department of Materials Science and Engineering, Faculty of Engineering, \\ Kyushu Institute of Technology, Kitakyushu
}

The Monte Carlo method combined with the static variational method is applied to a computer simulation on the phase decomposition process when the elastic constant of precipitates in a bcc binary alloy is harder than that of the matrix. The present study is compared with our previous results that were obtained for the case of the same elastic constant of the precipitates as that of the matrix in our previous report. We have adopted the Jonson-type potentials as the interaction between the constituent elements, and have used three kinds of interaction potentials between solute atoms.

We find an anisotropic structure in the alloy whose elastic constant of the precipitates is equivalent to the constant of the matrix. The alloy that has harder precipitates than the matrix shows an isotropic structure or a little anisotropic structure depending on the value of elastic constant of the precipitates.

We presume that the isotropic structure is yielded because of the larger contribution of the interfacial energy than the elastic strain energy. Evidently the total energy of the alloy with isotropic clusters is lower than that with anisotropic clusters for every potential used in the present simulation. Therefore we conclude that the formation of anisotropic clusters is not due to the shape of precipitates with the minimum elastic energy but due to the dynamical process of phase decomposition concerned with nonlinear many body effect.

(Received December 26, 1994)

Keywords: phase decomposition, computer simulation, pair-potential, elastic anisotropy, Monte Carlo method, variational method, nonlinear many body effect

\section{I . 緒 言}

弾性効果は相分解現象に括いて相の安定性や析出粒子の形状 などに影響を及ぼすことが知られている。弾性拘束が強い系に おいて析出物が母相より硬い場合は析出物の成長とともにその 形状が球状から板状中針状に变化し，異方的組織が生成する。 弾性雨エネルギーと析出物の形状について Eshelby ${ }^{(1)}$ 㔔等方的 媒質中に存在する整合介在物 (析出物)の歪エネルギーを線形弾 性モデルに基づいて初めて求めた。しかしながら，この理論で は単純な形状の介在物にしか適用でさない難点がある。 Khachaturyan ${ }^{(2)}$ は任意の形状の整合析出物飞対する弾性ニネ ルギーをフーリニ表現によって求めた．ただし，この理論は介 在物々母相の弾性定数が異なる場合火情必ずしも成立しない。 さらに，上述したこれら2つの理論はともに 1 粒子を対象と
している.

Johnson ${ }^{(3)}$ や Johnson と Cahn ${ }^{(4)}$ あるいは Miyazaki ら ${ }^{(5)} 2$ 粒子間の弾性相互作用などを考虑した分岐理論を提唱してい る.この理論によって，オストワルド成長とは逆に小さな粒子 が大きな粒子を吸取して粗大化し粒径が均一化する現象などが 解明された。しかしながら，これは合金の粒子寸法に伴ら諸相 互作用等を考慮して系全体のエネルギーが最小となる状態着 目したるので動的成長過程を取り报っていない，析出物の成長 過程を考慮した研究はVoorhees と Johnson ${ }^{(6)}$ 飞よって，2粒 子間が拡散と弹性場を通して相互作用を行っている粒子の成長 について行われている，攵の報告によると析出相が母相より硬 い場合，粒子の粗大化が生じることが予測されている。

Kawasaki とEnomoto ${ }^{(7)}$ 结, 平均場理論化弾性相互作用を取 り入れて析出粒子の粗大化過程を理論的に解析し，粒子が母相 より硬い場合は粗大化すると予測している.

実際の相分解過程は多数の粒子が互いに相互作用を行いなが 
ら進行しているので多数の粒子を考虑した取り扱いが望まし いしかしながら，これすで弾性効果を取り入れた場合，理論 的取り扱いが複雑になりかつ解析的な解が得られ難いため，低 合金濃度を対象として連続体近似や線形理論に基づいた解析が なされてきた。

近年, 計算機の急速な進歩により, 非線形方程式を数值計算 によって解くことが容易になった。 また，計算機を利用したシ

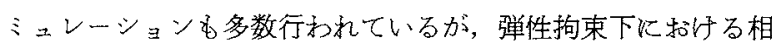
分解過程の動的解析の例は少ない。

Lee ${ }^{(8)}$ は整合歪が析出渦程に及ぼす影響をモンテカルロ法に よって研究している．ただし，等方的弾性体を仮定して弾性論 に基ついて歪ニネルギーや弾性相互作用エネルギーを求めてい るため，析出相と母相との弾性定数の相違などは考虑されてい ない. Onuki と Nishimori(9) は弾性相互作用等の弾性的効果 取り入れた Ginzburg-Landau 型の自由エネルギーによって2 次元結晶での計算機シミュレーションを行って，母相より硬い 析出物の形状が変化することを示している。 また，竹内ら $(10)$ は2 次元の連続体モデルによって非線形拡散方程式に基らい $\tau \mathrm{Al}-\mathrm{Zn}$ 合金と Fe-Mo 合金の相分解シミュレーションを行 い, 前者の等方的相分解之後者の異方的相分解が弾性歪の有無 によって生じることを示している.

以上の上う種々の方面から析出物の安定な形状や弾性效果 を考慮した相分解過程に関する研究がなされている。しかしな がら，3 次元の離散的な格子モデルに基づき弾性異方性を有す る結晶格子に特いて，母相上り硬い析出物が非線形多体効果を 伴って相分解を行ら動的過程に関する研究はこれまでのところ ほとんど報告されていない，我々はこれまで構成元素間に働く 2 体間相互作用ポテンシャルを仮定し，このポテンシャルによ って弾性異方性を有する3次元合金を想定し, モンテカル口 法と静的変分法を併用して，相分解過程について調べてきた。 前報(11)では，析出相の弾性定数が母相のそれより軟らかい場 合と同じ場合に拈ける相分解の動的過程を計算機シミュレーシ ョンKよって再現した．その結果, 前者では析出粒子の粗大化 に関する理論的予想とは異なり，析出相は1つの巨大なクラ スターを形成しパーコレート構造をとることが判明した。一 方, 後者は前诸とは全く異なり，パーコレートしれ構造をとら ず Fe-Mo 系合金にみられるよらな母相の〈100〉方に成長し た異方的な析出相が生成した。

本報告では母相より析出相の弾性定数が硬い場合に执いて異 万的相分解の生成過程について研究した結果を述べる。 また， すでに報告した母相と析出相の弾性定数が等しい場合の結果も 比較検討のため取り上げる。

\section{II. シミュレーションの方法および条件}

1. シミュレーションの方法

シミュレーションの方法はこれまでと同様でありその詳細は すでに報告した (12)。ここではその概略を簡単に述べる。

所定の濃度に相当する溶質原子や空孔を乱数により結晶中に 無秩序に配置し初期状態とした. 溶質, 溶媒原子の原子半径の 差による合金結晶内の格子歪を伴う相分解過程を次の上うな静 的変分洗 ${ }^{(13)(14)}$ とモンテカルロ法によって再現した。 まず, 乱
数によって任意に空孔を抽出し，その空孔から第11隣接内の 原子を対象として，各原子働く力度後述の相互作用ポテンシ ヤルから求め, その合力の方向各原子を徽小量変位させた。 この操作を各原子間の相互作用エネルギーの和が最小となるま で繰り返し行って格子を緩和し，その状態での結晶のエネルギ 一 $E_{1}$ 求めた。次に空孔のジンプ位置を最隣接位置の中か ら乱数によって決定して，空孔がその位置を占めた場合を想定 して前述と同様に格子を緩和させ，この状態での結晶のニネル ギー $E_{2}$ を求めた。このジャンプ前後の緩和した状態でのエネ ルギーの差 $\left(\Delta E \equiv E_{2}-E_{1}\right)$ を算出した。るし， $\Delta E \leqq 0 の$ 場合は 空孔をジャンプ位置に移動させ， $\Delta E>0$ の場合は遷移確率 $P_{\mathrm{ij}}$ $=\exp \left(-\Delta E / k_{\mathrm{B}} T\right)\left(k_{\mathrm{B}}\right.$ : Boltzmann 定数, $T$ : 絶対温度 $)$ 計 算し，計算機内で発生させた 0 から 1 すでの一様乱数 $R$ と比 較して, わし $P_{\mathrm{ij}} \geqq R な ら は ゙$ 空孔をジャンプさせ，逆の場合は 元の位置に留めるといらモンテカル口法の操作によって空孔を 移動させた．次に再び任意に空孔を抽出し同様の操作を繰り返 した. 空孔がジャンプを行ったか否かにかかわらずここ操作 の回数を時効時間 $t$ と定義した.

\section{2. シミュレーションの条件}

結晶構造はbccを想定して，計算機の容量を節約するため と演算速度の向上のため基本格子を用いた，格子点の総数 $N$ は27000個, 空孔濃度 $C_{\mathrm{V}}$ は $1.85 \times 10^{-3}$, 溶質原子濃度 $C_{\mathrm{S}}$ は 0.2 ，時効温度 $T$ は $1000 \mathrm{~K}$ を設定した。 また，結晶の表面の 影響を除くため周期的境界条件をとった。

Fig. 1 の各曲線は本シミュレーションで用いた構成元素間 のポテンシャルを示したものである. 図の横軸は距離 $r$ を格子 定数 $a$ で規格化している.曲線 M-M は溶媒原子間のポテンシ ヤルを表して我り，Johnson(15)が求めた $\alpha$ 鉄の 2 体間ポテン シャルを用いた。 をた曲線 M-S は溶媒原子と溶質原子間のポ

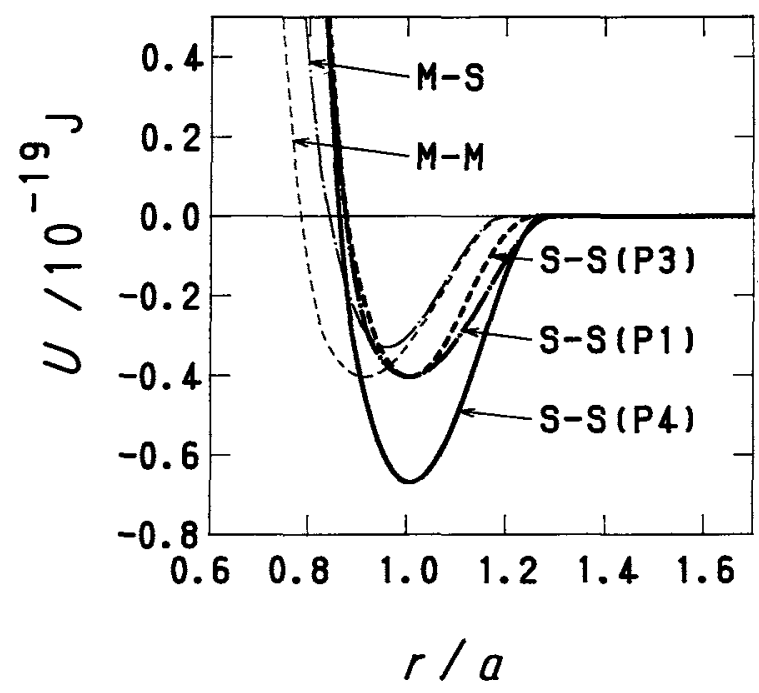

Fig. 1 Interatomic potentials $(U)$ used in the present simulations. Symbols S, M, $a$ and $r$ mean the solute atom, the solvent atom, the lattice parameter and the distance, respectively. The elastic constants calculated from the potentials $\mathrm{P} 3$ and $\mathrm{P} 4$ are harder than those from the potential P1. 
テンシャルである。本研究では 3 種類の合金を想定し, M-M, M-Sはすべて同一のポテンシャルを用いて溶質原子間のポテ ンシャル(曲線 S-S)のみ対しそれぞれ別のポテンシャルを使 用したそその中で P1 は曲線 M-M を図の右へ平行移動し，溶 質原子の半径が溶媒原子のそれより約 $10 \%$ 大きくなるように したものである。したがって，この場合の溶質原子間の弾性定 数は母相(溶媒原子)のそれと等しい，一方，曲線 P3は，極小 值やその位置はP1 と一致しているが曲線の形状が異なってお り，母相より硬い弾性定数を有する。また，曲線 P4 は極小值 がP1やP3より $2.65 \times 10^{-20} \mathrm{~J}$ 汪ど低いがその位置はP1や $\mathrm{P} 3$ と同様である.これらのポテンシャルは 2 原子間の距離 $r$ のみに依存して蚛り，方位低存性はない，弾性異方性は第 1 隣接や第 2 隣接間距離に敌けるポテンシャル曲線のてに関する 1 階や 2 階微分の值が異なることに起因している。充た，ポテ ンシャルの相互作用は短範囲ですり，第 2 隣接と第 3 隣接間 距離の間で 0 となる。長範囲に及ぶ弾性歪エネルギーや弾性 相互作用エネルギ一は前述した静的变分法を用いた格子の緩和 によって結晶内の各原子が次々と变位してポテンシャルェネル ギーの值が変化することによって生じる.

以上のポテンシャル曲線から Johnson ${ }^{(15)}$ が用いた計算式に 促ってP3，P4 および母相(P1)の弾性定数を求めた。これらの 弾性定数について P1 に対するP3，P4の比をTable 1 亿をと めた．P3 和よび P4 の弾性定数の比は 1 より大きく，母相よ り析出相が硬いことを示している。また，異方性パラメータの 值はP3と P4 は等しく母相のそれより大きい，

Table 1 Elastic constant ratios of solute atoms (subscript S) to solvent atoms (subscript M) obtained by potential curves of $\mathrm{P} 1, \mathrm{P} 3$ and $\mathrm{P} 4$. The symbol $A$ represents an anisotropic parameter.

\begin{tabular}{c|c|c}
\hline \hline & $\overline{\mathrm{P}}$ & $\mathrm{P} 4$ \\
\hline$\left(C_{11}-C_{12}\right)_{\mathrm{S}} /\left(C_{11}-C_{12}\right)_{\mathrm{M}}$ & 1.20 & 1.44 \\
\hline$\left(C_{44}\right)_{\mathrm{S}} /\left(C_{44}\right)_{\mathrm{M}}$ & 1.38 & 1.66 \\
\hline$(A)_{\mathrm{S}} /(A)_{\mathrm{M}}$ & 1.15 & 1.15 \\
\hline
\end{tabular}

\section{III. 結 果}

1. 各ポテンシャルによる構成要素間の結合および規則化エ ネルギー

上記のポテンシャルによる構成要素 $\mathrm{k}$ と1間( $\mathrm{k}, 1$ は空孔あ るいは溶質, 溶媒原子)の結合エネルギー $E_{\mathrm{kl}}^{\mathrm{b}}$ や規則化エネル ギー $V_{\mathrm{kl}}$ を以下のような方法によって求めた。をず， $E_{\mathrm{kl}}^{\mathrm{b}}$ Beeler ${ }^{(16)}$ と同様の方法によった。すなわち，k要素あるいは1 要素が溶媒原子によって構成されている結晶中に存在する場合 の爱和した状態での結晶の全エネルギー $\left(E_{\mathrm{k}}, E_{1}\right)$ から $\mathrm{k}$ 要素あ るいは1要素が存在しない状熊，すなわち全格子点が溶媒原子 によって占められている場合の結晶の全エネルギー $E_{0}$ を差し 引いたエネルギー $\left(E_{\mathrm{k}}^{\mathrm{c}}, E_{\mathrm{l}}^{\mathrm{c}}\right)$ を求め, 式 $(1)$ にっって $E_{\mathrm{kl}}^{\mathrm{b}}$ 算出 した.

$$
E_{\mathrm{kl}}^{\mathrm{b}}=E_{\mathrm{k}}^{\mathrm{c}}+E_{\mathrm{l}}^{\mathrm{c}}-E_{\mathrm{ki}}^{\mathrm{c}}
$$

ここで $E_{\mathrm{k} 1}^{\mathrm{c}}$ は結晶中に構成要素 $\mathrm{k}$ と 1 が第 1 䇟接位置あるい は第 2 陃接位置で詨を形成している場合の緩和状態に和ける 結晶の全エネルギー $E_{\mathrm{kL}}$ から $E_{0}$ を差し引いたエネルギーであ る.よって結合エネルギーには $\mathrm{k}, 1$ 間のみの相互作用エネルギ 一だけではなく，結晶の緩和によって生じた隣接する各原子の 変位によるエホルギーの変化も含まれている.式(1)の定義 から $E_{\mathrm{kl}}^{\mathrm{b}}$ の值が正の場合は対を形成するとエネルギーが低下し て k1 対が形成され易いことを意味している。

規則化エネルギー $V_{\mathrm{kl}}$ は式 (2)Kよって求められる(17)

$$
V_{\mathrm{kl}}=E_{\mathrm{kl}}^{\mathrm{c}}-\left(E_{\mathrm{kk}}^{\mathrm{c}}+E_{\mathrm{ll}}^{\mathrm{c}}\right) / 2
$$

この式からわかるょらに $V_{\mathrm{kl}}$ の值が正である場合, $\mathrm{kl}$ 対は 形成さ就難いことを意味する。

Table 2 はこれらの結果のまとめたるのである、ポテンシャ ル曲線 M-M や M-S は 3 種類の合金に対してすべて同一であ ることを反映して，Table $2 の$ 各隣接位置での $E_{\mathrm{SV}}^{\mathrm{b}} や E_{\mathrm{VV}}^{\mathrm{b}}$ は それぞれ等しい值となって必り， $V_{\mathrm{MV}}$ すポテンシャルのいか んにかかるらず等しい結果となっている.

S-S 間のポテンシャルは Fig. 1 Kみられるように P1, P3 お よび $\mathrm{P} 4$ と互いに異なっているため， $E_{\mathrm{SS}}^{\mathrm{b}}$ の值の計算結果も各 ポテンシャルKよって相違している． $E_{\mathrm{SS}}^{\mathrm{b}}$ の $\mathrm{P} 1$ と 3 の値に 着目すると，第 2 隣接位置の值は両者とも等しいが第 1 隣接

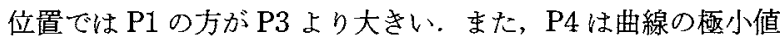

Table 2 Binding $\left(E_{\mathrm{kl}}^{\mathrm{b}}\right)$ and ordering energies $\left(V_{\mathrm{kl}}\right)$ between $\mathrm{k}$ and l occupying on the first and the second nearest neighbor site (n.n.s.) obtained by using potentials of $\mathrm{P} 1, \mathrm{P} 3$ and $\mathrm{P} 4$. Symbols $\mathrm{k}$ and 1 represent constituents: a solute atom (S), a vacancy (V) and a solvent atom $(\mathrm{M})$.

\begin{tabular}{c|c|c|c|c|c|c}
\hline & \multicolumn{2}{|c|}{ P1 } & \multicolumn{2}{c}{ P3 } & \multicolumn{2}{c}{ P4 } \\
\hline & 1 st n.n.s. & 2 nd n.n.s. & 1 st n.n.s. & 2 nd n.n.s. & 1 st n.n.s. & 2 nd n.n.s. \\
\hline$E_{\mathrm{S} S}^{\mathrm{b}} / 10^{-20} \mathrm{~J}$ & 1.28 & 2.36 & 0.790 & 2.36 & 3.04 & 5.01 \\
\hline$E_{\mathrm{SV}}^{\mathrm{b}} / 10^{-20} \mathrm{~J}$ & 3.29 & -0.282 & 3.29 & -0.282 & 3.29 & -0.282 \\
\hline$E_{\mathrm{VV}}^{\mathrm{b}} / 10^{-20} \mathrm{~J}$ & 2.21 & 3.03 & 2.21 & 3.03 & 2.21 & 3.03 \\
\hline$V_{\mathrm{MS}} / 10^{-20} \mathrm{~J}$ & 0.638 & 1.18 & 0.395 & 1.18 & 1.52 & 2.51 \\
\hline$V_{\mathrm{SV}} / 10^{-20} \mathrm{~J}$ & -1.54 & 2.98 & -1.79 & 2.98 & -0.659 & 4.31 \\
\hline$V_{\mathrm{MV}} / 10^{-20} \mathrm{~J}$ & 1.11 & 1.52 & 1.11 & 1.52 & 1.11 & 1.52 \\
\hline
\end{tabular}


が低いため第 1 第 2 隣接位置ともに $E_{\mathrm{SS}}^{\mathrm{b}}$ は $\mathrm{P} 1$ や $\mathrm{P} 3$ のそれ代 対して約 2 倍程の值となって敌り，溶質原子対の生成が容易 なことがわかる。また，いずれのポテンシャルと执いてる第 1 隣接位置の值上り第 2 隣接位置の値の方が大きいことは, 第 2 隣接位置間の〈100〉方向に溶質原子対を形成する方が第 1 隣接 位置間の〈111〉方向よりェネルギー的に有利で岁ることを示し ている、これ化よって本シミェレーションではクラスターが異 方的比長卞る傾向をむつことがわかる。

\section{2. 相分解過程}

結晶全体の原子配列状態に関する情報を得るため $\mathrm{x}, \mathrm{y}$ 平面 上の各格子点での $z$ 軸方向の溶質原子濃度を求めた. 本シミュ レーションで用いたbcc の基本格子を通常の格子に変換する 之, 単位胞が $\mathrm{x}, \mathrm{y}$ 方向にそれぞれ30個， $z$ 万向に15個積み重 なった直方体になる，この值方体の底面比 $z$ 方向の溶質原子濃 度を各格子点毎に表示した図が Fig. 2である. 同一時刻時間 $t$ に対する 3 者の空孔のジャンブ回数 $N_{\mathrm{j}}$ が異なっていたので, それぞれの $N_{\mathrm{j}}$ がほ活等しい時効時間を選んだ。(a)図はすで に報告した図であり(11)，翼方的スピノーダル分解の透過型電 子顕微鏡写真 ${ }^{(18)(19)}$ と類似している. (b) 図は (a) 図に比べて $〈 100\rangle$ 方向への配向が明膫ではない，また，(c)図は(a)図や

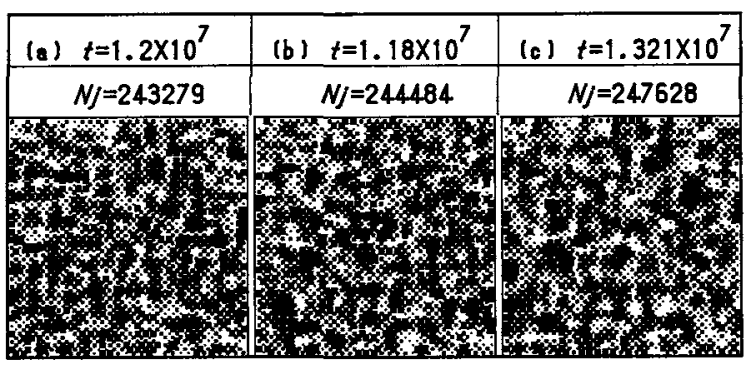

$\square C_{s}=0 \quad$ Q $0<C s \leqq 0.067 \quad 0.067<C_{s} \leqq 0.2$

$[010]$

$0.2<C_{s} \leqq 0.4 \square 0.4<C_{s}$

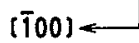

Fig. 2 Concentration variations aged for long time by using various potentials. (a): $\mathrm{P1},(\mathrm{b}): \mathrm{P} 3,(\mathrm{c}): \mathrm{P} 4$. (b)図上り全体的に組織が粗くかつ等方的スピノーダル分解に みられる組織と類似している。

以上の結果から，異方的相分解を最も顕著に示しているのは (a) 図の母相と析出相の弾性定数が等しい場合で，母相より硬

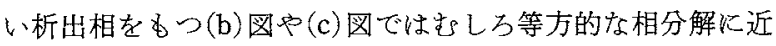
い原子配列状態となっている。

前報(11)で報告した母相より析出相が軟らかい場合, 溶質原 子は互いに第 1 隣接位置で連なり大きな 1 つのラスターを 形成した。しかしながら，今回の舟相より硬い析出相の場合は 互いに孤立した多数のクラスターが生成しているここでクラ スターとは溶質原子が互いに第 1 隣接位置で連なって配列し ている状態であり，クラスターの寸法はそれを構成する溶質原 子数で表す. Fig. 3 は合金結晶内に生成したクラスターの寸 法分布を示したものである. $Y(n)$ は $n$ といら寸法のクラスタ 一の個数を表す。ただし，この図炕いて $Y(n)$ の值はnの値 を10段階每の級間隔にした場合の度数を意味する。図の(a), (b), (c) 恃 Fig. 2 の (a)，(b)，(c)の各図にそれぞれ対応する. Fig. 3 によると(a), (b), (c) と析出相の弾性定数が硬くなって いる順に寸法分布の幅が広がって䊅り，(c)では図中の棒グラ フで示したクラスターの他に $n=938$ という大きなクラスター 手生成している。

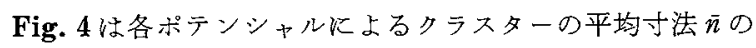
時効時間 $t$ 亿伴ら変化を表したるのである.P1 と P3のポテ ンシャルによるクラスターの成長過程はほとんど同様である. 一方，P4 のポテンシャルによる合金ではP1やP3より成長が 著しい。

次に溶質原子の短範囲の配列状態関する知見を得るため， Warren-Cowley の短範囲規則度 $\alpha_{\mathrm{i}}$ を求めた ${ }^{(20)(21)} ， \alpha_{\mathrm{i}}$ は式 (3) で定義される。

$$
\alpha_{\mathrm{i}}=1-\frac{p_{\mathrm{BA}}}{c_{\mathrm{A}}}
$$

ここで， $c_{\mathrm{A}}$ は A-B 2 元系合金の $\mathrm{A}$ 原子の濃度， $p_{\mathrm{BA}_{\mathrm{i}}}$ はある 1 つの格子点に $\mathrm{B}$ 原子があるとき，その $\mathrm{B}$ 原子から $i$ 番目の隣 接距離に $\mathrm{A}$ 原子がある確率を意味し， $Z_{\mathrm{i}}$ を $i$ 番目の隣接距離 の配位数， $n_{\mathrm{A}_{\mathrm{i}}}$ ををの中の $\mathrm{A}$ 原子の個数とすると， $p_{\mathrm{BA}_{\mathrm{i}}}=n_{\mathrm{A}_{\mathrm{i}}} / Z_{\mathrm{i}}$ である.Fig. 5 は各ポテンシャルによる合金の $\alpha_{\mathrm{i}}$ の時間変化
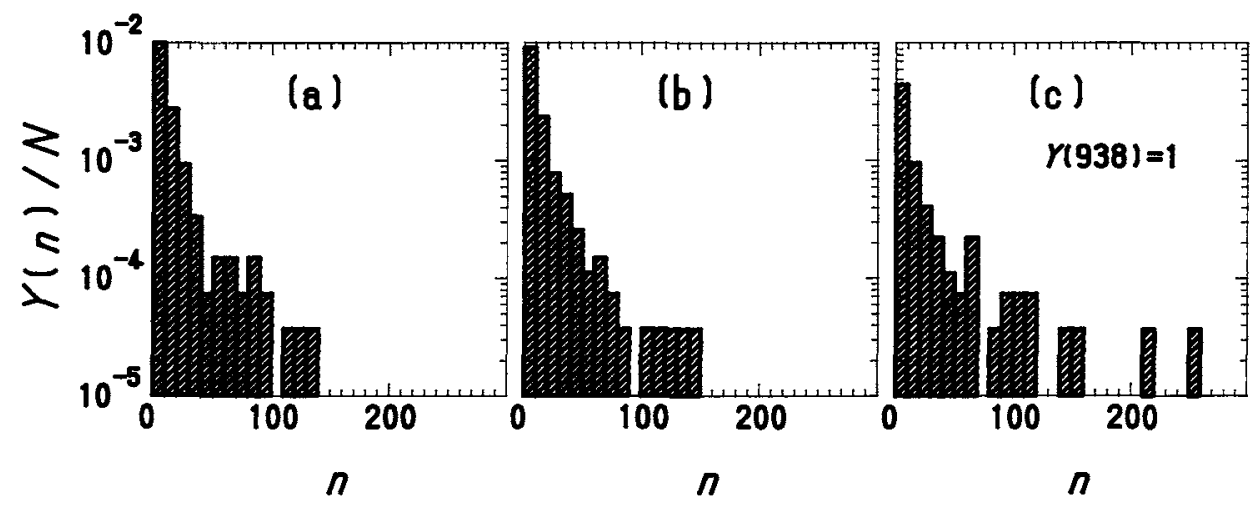

Fig. 3 Size distributions of clusters in various alloys as shown in Fig. 2. Symbols $Y(n)$ and $N$ represent the number of clusters containing $n$ solute atoms and the total number of crystal sites, respectively. In Fig. (c), a large cluster $(n=938)$ is also generated. 


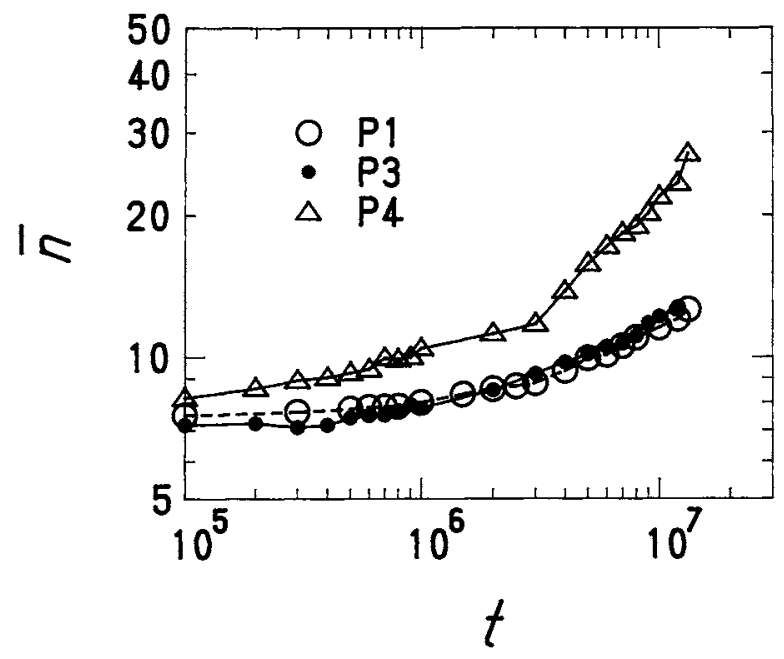

Fig. 4 Mean size of clusters $(\bar{n})$ versus aging time $(t)$ in the alloys with $\mathrm{P} 1, \mathrm{P} 3$ and $\mathrm{P} 4$.

についてまとめたものである。添字iは，着目する原子を中心 として $i$ 番目の隣接距離を意味する。 $\alpha_{\mathrm{i}}=0$ は $i$ 番目の隣接距 離の配位原子炕括いて完全不規則状態を， $\alpha_{\mathrm{j}}>0$ 以着目する原 子との同種原子対が多いことを， $\alpha_{\mathrm{i}}<0$ は着目する原子との異 種原子対が多いことをそれぞれ表す。また，長範囲規則性がな いときには，iの堌大とともに $\alpha_{\mathrm{i}}$ は 0 に近づく、クラスターの 平均守法の時間変化の結果と同様, (a) 図の P1 と(b)図のP3 の $\alpha_{\mathrm{j}}$ の形状活いずれの時效時間(この図では $N_{\mathrm{j}}$ )に対しても压 とんど同様である。これら両者の $\alpha_{\mathrm{i}}$ は時效時間が最も長い状 態沁颃いて，第 1 隣接上り第 2 隣接の值が大きく，第 3 第 4 隣接ではほぼ 0 となり第 5 隣接で再び増加して第 6 第 7 隣接 と距離が増加するにつれて0に近ついている。これは溶質原 子の異方的分布を反映しているためと考光られる，したがっ て，ボテンシャルP3による相分解の状態は Fig. 2(b)では一 見等方的比見克たが，P1 之同样異方性がある。一方，(c)図の $\mathrm{P} 4$ Kよるポテンシャルの合金で第1隣接と第 2 隣接の $i$ の 値が活淁しく，第 3 第 4 隣接の間で 0 に減少し第 5 隣接以 上の距離ではゆらぎはあるるののほぼ0となっている。すな わちこの場合にも $\mathrm{P} 4$ のポテンシャルKよる合金では異方的相 分解を示吉結果は得られていない。

\section{3. 構造関数による解析}

相互作用ポテンンャルの各值による相分解過程について溶質 原子の空問的配置をフーリエ変換した構造関数 $S(k)(k$ は波数 を意味し， $\lambda$ を波長とすると $k=2 \pi / \lambda$ と定義される)によって 調ベた，構造関数は $k$ と $t$ 関数であるが，簡単のため $t$ を省 略した。この $S(k)$ は X線や中性子線などの小角散乱の強度分 布に相当するもので，次のよ5にして求めた．原点加ら任意の 距離 $\boldsymbol{r}_{\mathrm{j}}$ にある格子点 $\mathrm{j}$ を溶質原子が占有しているとき $C\left(\boldsymbol{r}_{\mathrm{j}}\right)$ $=1$ ，その他の場合は 0 として, 溶質原子の空間的配置を式 (4) のようにフーリェ変換した。

$$
S(\boldsymbol{k})=\frac{1}{N}\left|\sum_{j=1}^{N} C\left(\boldsymbol{r}_{\mathrm{j}}\right) \exp \left(i \boldsymbol{k} \boldsymbol{r}_{\mathrm{j}}\right)\right|^{2}
$$

(a)

(b)

(c)

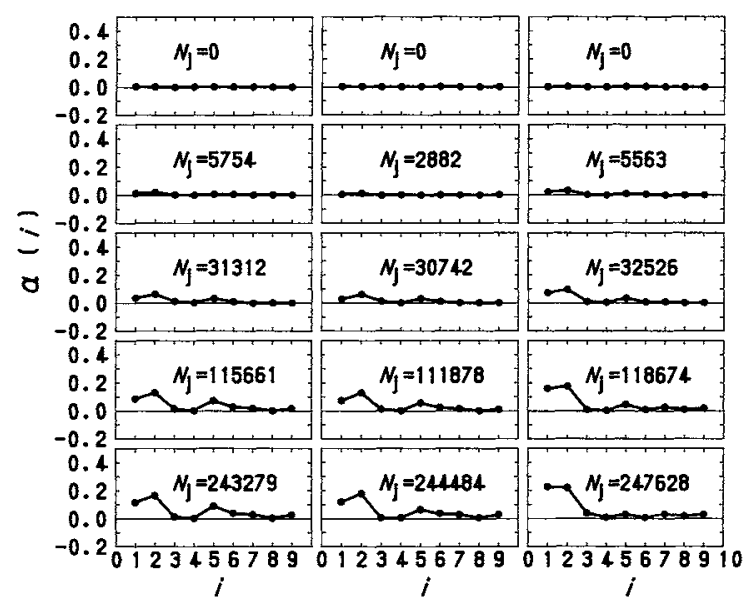

Fig. 5 Warren-Cowley's short range order parameters $\left(\alpha_{\mathrm{i}}\right)$ at various aging time. A symbol $i$ means a neighbor distance. (a): P1, (b): P3, (c): P4.

ここで, $N$ は格子点の総数， $\boldsymbol{k}$ は波数ベクトルを表し,$k=2 \pi$ $\left(\boldsymbol{k}_{\mathrm{x}}, \boldsymbol{k}_{\mathrm{y}}, \boldsymbol{k}_{\mathrm{z}}\right) / 15 a$ であり，a格子定数で簡単のため 1 と打い た. $\boldsymbol{k}_{\mathrm{x}}, \boldsymbol{k}_{\mathrm{y}}, \boldsymbol{k}_{\mathrm{z}}$ の值は乞れぞれ1から15までとした。

Fig. 6 は〈100〉方向と〈111〉方向飞括ける $S(k)$ の時間变化を まとめたものである，(a)図は P1，(b)図はP3，(c)図はP4の ポテンシャルによる結果で，この中の(a)眓は前報と同様であ る(11).Fig. 5(a)，(b)火見られたよら飞溶質原子の濃度分布 には異方性があるため Fig. 6 の (a) 図，(b)図ともに〈111〉方向 の $S(k)$ の発達はく100〉方のそれに比べて少ない．しかしなが b，(b)図のS(k)の極大值は(a)図に比へてて低い，また，(c)図 ではく100〉万向の $S(k)$ の極大值は(b)図のそれより低くなだら かな変化をしている．その反面，〈111〉方向に和ける $S(k)$ の極 大值が他炕此べて大きい

次飞合金結晶全体の小角散乱強度に対応する $S(k)$ を求める ため，全方向関する $S(\boldsymbol{k})$ 火対して $|\boldsymbol{k}|$ の整数值毎に平均し て $S(k)$ を求めた．Fig.7は孛の結果である。この图において も(a)図のP1Kよるポテンシャルの結果は前報と同様であ る(11). (b) 図はポテンシャル P3，(c)図はポテンシャルP4K よる結果である．注目される点は，Fig. 6 の〈100〉方向の $S(k)$ は (a) (b) (c) 図の順に極大值が低くなっていたが，この Fig. 7 ではこ机とは逆江極大值が大きくなって括り，(c)図のポテン シャルP4による合金が最も大きい極大值を示している。 また， (b) (c) 図では極大値に対応する $k$ の值 $k_{\mathrm{m}}$ は $N_{\mathrm{j}}$ の増大に伴 って $k$ の值の小さい方へ移動している． $k_{\mathrm{m}}$ はこの波数に相当 する濃度ゆらぎの波の成分が合金中に最も多いことを意味す る.この $k_{\mathrm{m}}$ は (a) 図や (b), (c) 図の時效初期段階では $S(k)$ の 極大值が明膫でないため, 式(5)によって定義される構造関 数の 1 次モーメント $k_{1}$ を求め $k_{\mathrm{m}}$ の代わりとした。

$$
k_{1}=\frac{\sum_{k} k S(k)}{\sum_{k} S(k)}
$$




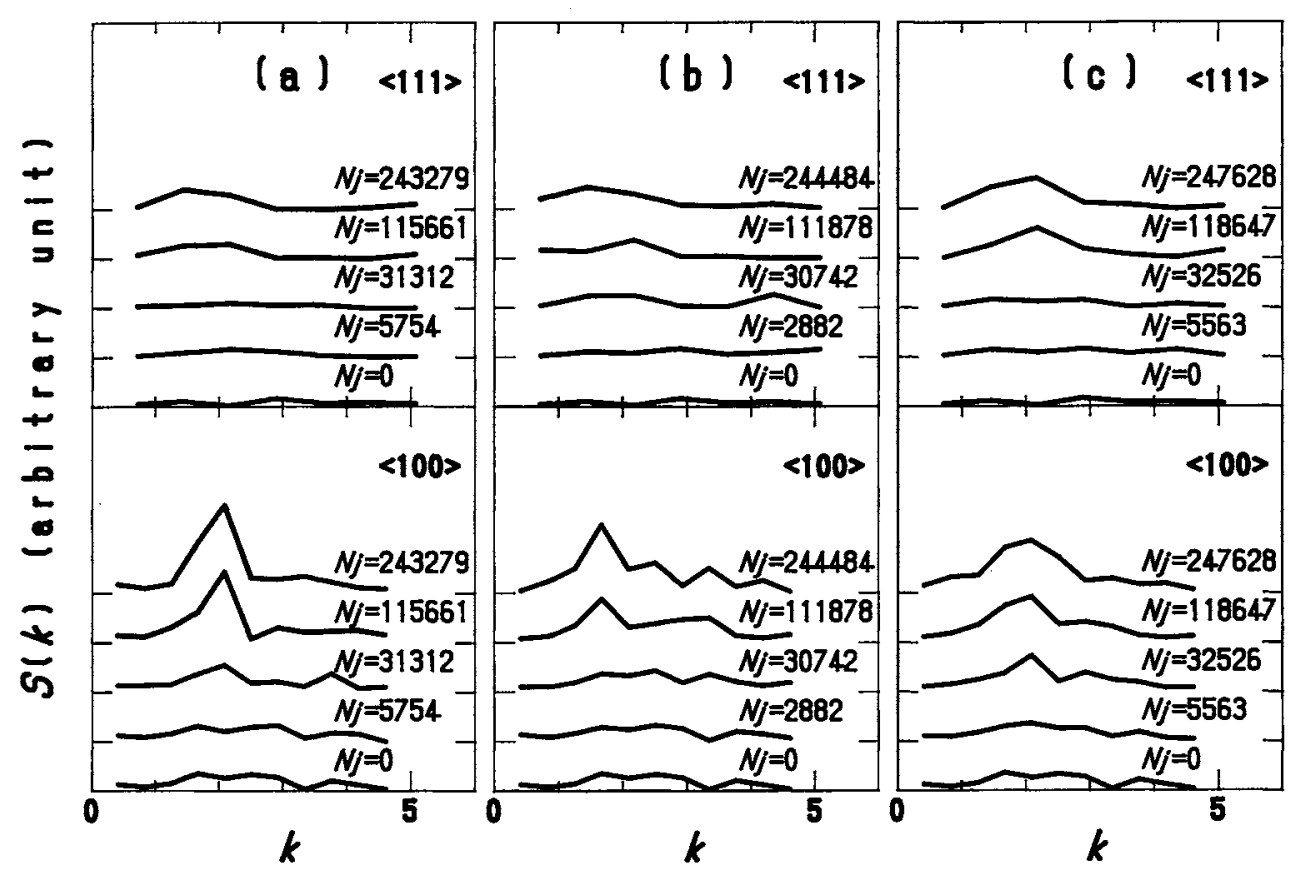

Fig. 6 Structure functions $(S(k))$ of spatial distributions of solute atoms along $\langle 111\rangle$ and $\langle 100\rangle$ directions. The symbol $k$ means wave number. (a): P1, (b): P3, (c): P4.
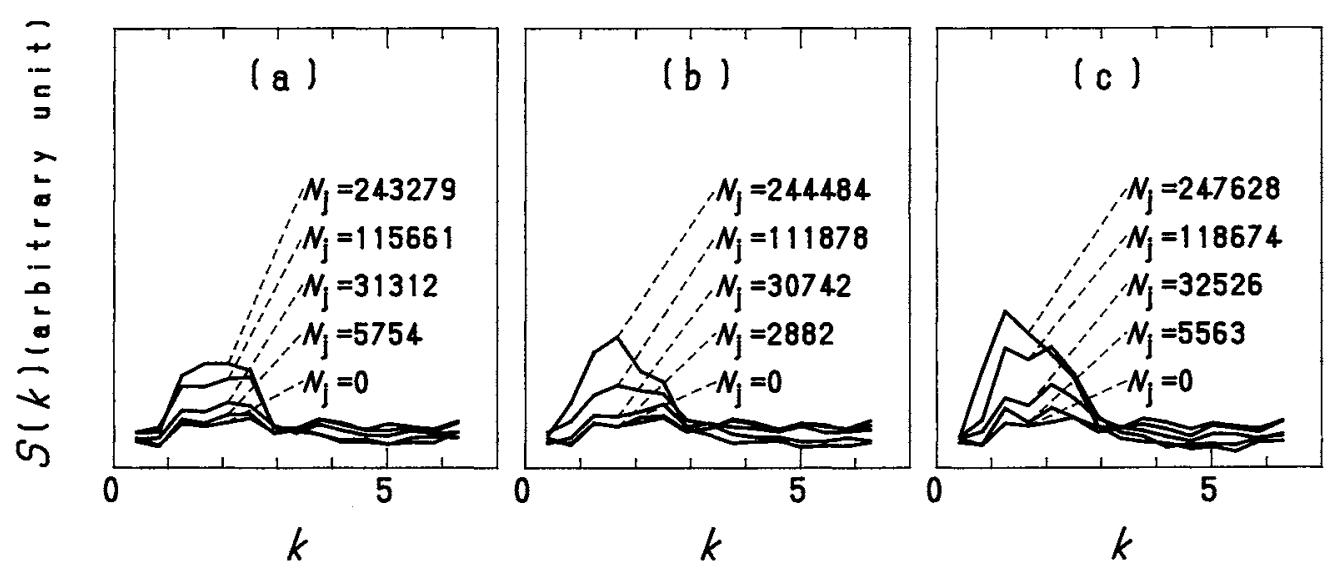

Fig. 7 Structure functions $(S(k))$ averaged spherically. (a): P1, (b): P3, (c): P4.

この時間変化を Fig. 8 に図示している.P1の各点はtの増大

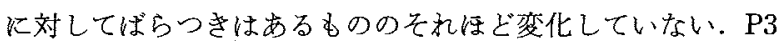
は, Fig. 4 のクラスターの平均寸法や Fig. 5 の短範用規則度 の結果ではP1 と同様の傾向であったが，この $k_{1}$ にいては $t=10^{7}$ 付近で $\mathrm{P} 4$ の結果と注ぼ同じ值をとっている.P4は $t$ の増加とともに次第に減少している。

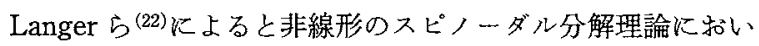
て, 長範囲にわたる相互作用が市る場合, Cahn ${ }^{(23)}$ の線形近似 が時效初期段階で成立すると述べている。一般に，このよ5な 長範囲の相互作用がない等方的合金に和いては Cahn の線形理 論は成立せず， $k_{1}$ は時効の極く初期段階から $k$ の值の小さい 万へ変化することが知られている.したがって，P1のポテン シャルを使用した合金では $k_{1}$ がほぼ一定であることから長範
用相互作用によって線形近儲が成立し，P3 P P4のポテンシ ヤルによる合金では非線形效果が大きいことが推定される。こ の上らな長範囲相互作用は前に述へたように各原子の変位が次 々と起こることによって生じる。

\section{N. 考察}

緒言で述べたように，弾性拘束が強い合金中の母相より硬い 析出物はとの成長とともに形状が球状から板状あるいは針状に 変化し異方的な組織となる。こ玌には弾性エネルギーや界面工 ネルギーをはじめとして母相や析出物の異方性の有無など種々 の因子が影響するため単純ではないが，析出相の硬さのみが異 なりその他の因子に上る寄与が同様な場合，一般に母相上り硬 


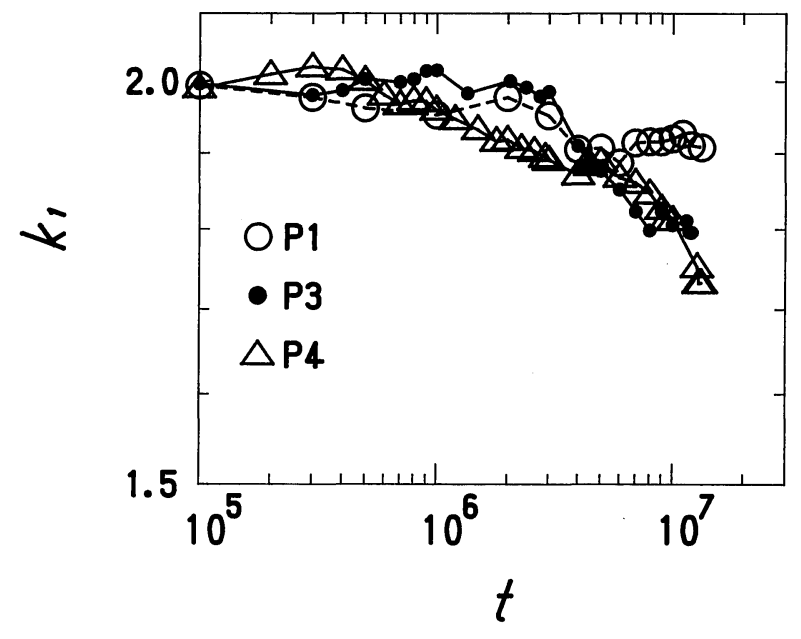

Fig. 8 Time evolution of the first moment of the structure functions $\left(k_{1}\right)$.

い析出相注ど異方性が顕著になると考えられる．

しかしながら本結果では，異方的な相分解は母相と析出相の 弾性定数が等しい合金に最も明瞭に現れ，母相より硬い析出相 のP3 のポテンシャルによる合金では異方性が小さい。また， P4 のポテンシャルでは弾性定数が P3 より硬いにもかかわら ず等方的な相分解が生じている.この点について考察する.

一般に相分解を生じている合金の全自由エネルギー $G_{\mathrm{T}}$ は式 ( 6 )のように種々の因子の寄与の和として与兄られる ${ }^{(24)}$.

$$
G_{\mathrm{T}}=G_{0}+\Delta E_{\mathrm{str}}+\Delta E_{\mathrm{surf}}+\Delta G_{\text {chem }}+\Delta E_{\text {int }}
$$

$G_{0}$ は 2 相分離した組織の化学的エネルギー， $\Delta E_{\text {str }}$ は弾性歪エ ネルギー, $\Delta E_{\text {surf }}$ は界面エネルギー, $\Delta G_{\text {chem }}$ は濃度変動に伴 万化学的な過剩エネルギー, $\Delta E_{\text {int }}$ は析出粒子間の弾性相互作 用エネルギーを表す. 本シミュレーションで用いた 2 体間相 互作用ポテンシャル曲線は式 (6)の各項を含んでいるといら 長所をるつ反面，これらの寄与を分離できないという短所があ る.よって, 本結果について, 式(6)k和ける個々のェネル ギーの寄与がどの程度であるかを評価できない. P4 のポテン シャルはFig. 1 に示されているよらに, 極小值が他のポテン シャルより小さい，したがって，界面エネルギーが，異方性に 影響を及湆す弾性歪エネルギーなどを上回ったため等方的な相 分解が生じたものと考えられる。

P3 のポテンシャル曲線は極小の位置や值が P1 と等しくそ の形状のみが P1 と異なり，ょり硬い弾性定数を有する.よっ て, P3 のポテンシャルによる合金はP1のそれより顕著な異 方性を示すと予想される.ところがシミュレーションの結果, 異方性は現れたもののP1 より異方性に乏しい組織が生じた. この原因を調べるため次の計算を行った．まず，各ポテンシャ ルで最もェネルギーの低い原子配列状態はどのようなものかを 求めるため, それぞれのポテンシャルによって相分解が進行し た状態に括ける原子配列に対して他のポテンシャルによって合 金の全相互作用エネルギーを算出した。一例をあげると, Fig. 2(c)はP4 のポテンシャルによって生じた配列によるものであ るが，この原子配列に対して P1, P3 のポテンシャルを用いて その全相互作用エネルギーを求めた。 このよらにして算出した
Table 3 Total energies $(E)$ of alloy crystals with the potentials (a): P1, (b): P3 and (c): P4 The underlined values are obtained by using original potentials for respective alloys.

\begin{tabular}{c|c|c|c}
\hline \hline & \multicolumn{3}{|c}{$E / 10^{-15} \mathrm{~J}$} \\
\hline Alloy & P1 & P3 & P4 \\
\hline (a) $t=1.2 \times 10^{7}$ & -5.80 & -5.77 & -6.05 \\
\hline (b) $t=1.18 \times 10^{7}$ & -5.81 & -5.78 & -6.06 \\
\hline (c) $t=1.321 \times 10^{7}$ & -5.84 & -5.80 & -6.14 \\
\hline
\end{tabular}

\section{値を Table 3 にまとめた.}

表中の (a)，(b)，(c)はそれぞれ P1, P3, P4 のポテンシャル によって生じた相分解の原子配列によるものである. (a) (b) (c)の各原子配列状態ではポテンシャル P4 による結晶の全エ ネルギーが最も低い.これはFig. 1 にみられるよらにP4のポ テンシャル曲線の極小值が他のポテンシャルの極小值より低い ことによるものと考觉れる.

興味深い点は, P1 のポテンシャルによって生じた原子配列 状態による $E$ の值は(a)であるにもかかわらず, 最もエネルギ 一が低い配列状態は(c)の P4によって生成した組織であると いう結果である. P3 のポテンシャルについても同様である. すなわち, P4 を除いたその他のポテンシャルでは, 結晶のエ ネルギーはそれぞれ各ポテンシャルによって相分解の結果生じ た原子配列状態のエネルギーより，P4によって得られた配列 状態の方が低いことが判明した. しかも，このP4によって生 じた原子配列状態は異方性がない状態である. 次の疑問は, P1 P 3 のポテンシャルによって, エネルギーの高い異方的 な配列状態がなぜ生成したかといら点である．この原因を調べ るため 3 個の溶質原子がクラスターを形成する場合のエネル ギー変化を P1, P3, P4 のポテンシャルについて求めた。 その クラスターはFig.9の各図に黒丸で示している. 図中の数字 は空孔(正方形) と位置交換を行って図に示す黒丸のクラスター が生成する場合のいくつかの経路を表している．1番から 3 番 までの場合は溶質原子が互いに最隣接位置にあり，いわば等方 的なクラスターが生成することを想定している．4 番から 6 番 までは〈111〉方向に，また 7 番から10番までは〈100〉方向に 3 個の溶質原子が配列する場合を仮定している．以上の各場合に ついて空孔と位置交換する前後のエネルギー変化 $\Delta E$ を求め た。それらの值を Table 4 亿示す. $\Delta E>0$ はクラスターの生 成によりエネルギーが増加し，クラスター形成が困難であるこ とを意味する. Table 4 の A は溶質原子 3 個と空孔 1 個のみ の合金に和ける結果である.P1, P3 のポテンシャルによる合 金では, 1 番から 3 番までの $\Delta E$ の值の中で 3 番のみが負であ るが，P4では 2, 3 番が負の值となって扣り $\mathrm{P} 4$ のポテンシャ ルによる合金において等方的な組織が生成していたことを裏付 けている。また， 4 番から 6 番までの $\Delta E$ の值はポテンシャル のすべてに対して正であり〈111〉方向へのクラスターの配向が 困難であることを示している.一方， 7 番から10番までの $\Delta E$ の值はすべてのポテンシャルで負となっている.このことから 〈100〉方向へのクラスターの成長がエネルギー的に容易である ことがわかる. 

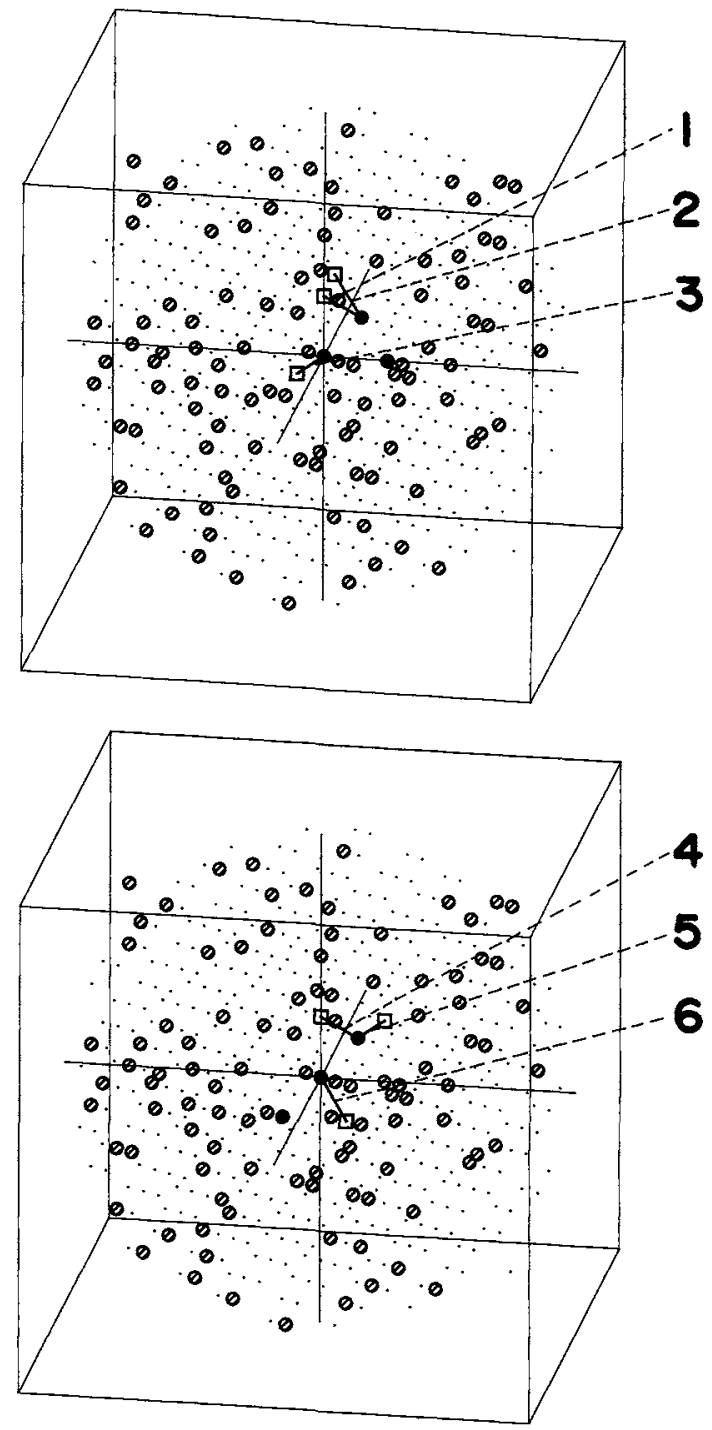

Table 4 Values of the total energy changes $(\Delta E)$ of alloy crystals in forming a cluster by exchange of a vacancy and a solute atom via various migration paths as shown in Fig. 9. A positive value indicates increase of the energy in forming a cluster. The symbols $A$ and $B$ denote the case containing 3 solute atoms and one vacancy, and 5403 solute atoms and 51 vacancies, respectively. Each value listed in B is an average of 5000 configurations.

\begin{tabular}{|c|c|c|c|}
\hline $\mathrm{A}$ & \multicolumn{3}{|c|}{$\Delta E / 10^{-20} \mathrm{~J}$} \\
\hline Migration path & $\mathrm{P} 1$ & P3 & $\mathrm{P} 4$ \\
\hline 1 & 4.73 & 5.64 & 3.56 \\
\hline 2 & 2.01 & 2.73 & -2.24 \\
\hline 3 & -1.221 & -0.602 & -5.57 \\
\hline 4 & 5.72 & 6.36 & 6.84 \\
\hline 5 & 2.81 & 3.52 & 1.55 \\
\hline 6 & 5.93 & 6.82 & 5.07 \\
\hline 7 & -2.49 & -2.52 & -5.18 \\
\hline 8 & -3.85 & -4.29 & -4.69 \\
\hline 9 & -6.48 & -6.88 & -9.89 \\
\hline 10 & -3.85 & -4.29 & -4.69 \\
\hline $\mathrm{B}$ & \multicolumn{3}{|c|}{$\Delta E / 10^{-20} \mathrm{~J}$} \\
\hline 1 & 5.46 & 4.92 & 4.17 \\
\hline 2 & 1.97 & 2.11 & -1.50 \\
\hline 3 & -0.757 & -0.724 & -4.48 \\
\hline 4 & 6.91 & 5.85 & 8.01 \\
\hline 5 & 3.58 & 2.78 & 2.30 \\
\hline 6 & 6.81 & 6.01 & 5.60 \\
\hline 7 & -2.47 & -2.29 & -4.52 \\
\hline 8 & -3.92 & -3.65 & -4.43 \\
\hline 9 & -6.33 & -6.09 & -9.01 \\
\hline 10 & -4.13 & -3.80 & -4.51 \\
\hline
\end{tabular}

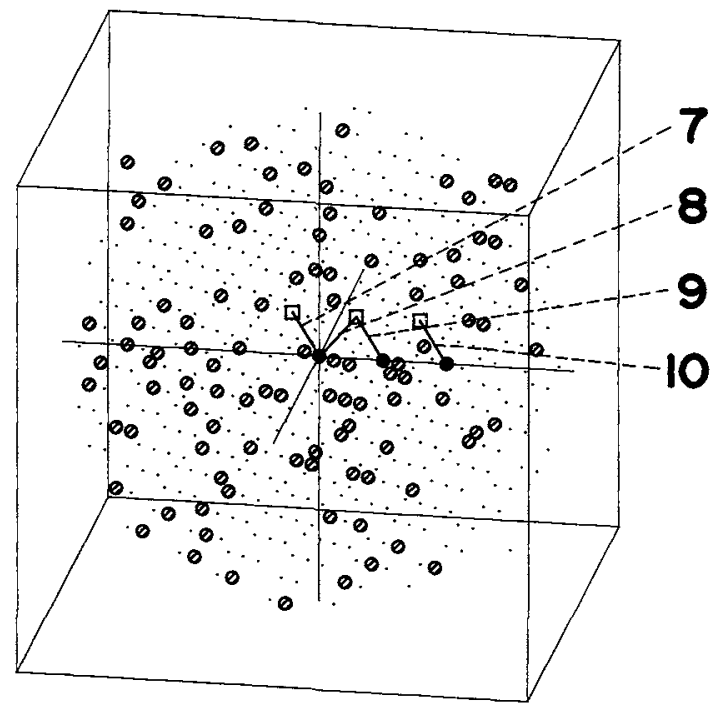

Fig. 9 Various migration paths (numbers from 1 to 10 ) for forming a cluster containing three solute atoms (full circles) by exchange of a vacancy (a square) and a solute atom (a full circle). The dots and the shaded circles represent other solvent atoms and solute atoms than forming the cluster, respectively.

しかしながら，P1 と P3の值を比較すると1番から6 番悉 で $\mathrm{P} 1<\mathrm{P} 3$ となって就り，P1のポテンシャル炕よって生成す る溶質原子のクラスターはP 3 のポテンシャルル上るクラスタ 一に比べて，等方的配列や〈111〉方向に配列したクラスターが 生成し易いことを意味して括り，シミュレーション結果に反す る。また〈100〉方向のクラスター形成についてもシミュレー ション結果と矛盾する.

そこで，溶質原子 3 個だけでなく寒際のシミュレーション と同様の溶質原子と空孔がランダムに存在する場合に和けるエ ネルギー变化を求めた。 この結果を同表のBに示す。ただし， これらの值は5000種類の配列状態の結果を平均したものであ る.この場合は, 2 番と 3 番以外は $\mathrm{P} 1$ と 3 の大小関係は $\mathrm{A}$ の結果とは逆転しておりシミュレーション結果と泳ぼ一致する 傾向を示している。

以上のことから次のことが判明した。ここで用いたいずれの ポテンシャルKついても, 異方的な溶質原子の配列上り等方的 な配列の万がェネルギー的に低く安定である、ポテンシャル P1，P3に異方的原子配列が生じた原因は，クシスタ一形成過 
程に执いて他の溶質原子や空孔との相互作用によって，クラス ターが異方的に成長するような原子移動の経路がエネルギー的 に低いからである。しかもこのエネルギーの低い状態は，結晶 中に溶質原子が $2 ， 3$ 個ではなく多数存在する状態で生でて接 り非線形多体効果が関与している。すなわち, 本シミュレーシ ョンで用いたポテンシャルでは，Eshelby(1)や Khachaturyan ${ }^{(2)}$ の理論で予測されるエネルギー的に最も安定な析出物の形状を とるようにクラスターが異方的に成長するのではなく，相分解 の動的過程炕よるためであると結論される。

\section{V. 結 言}

モンテカルロ法と静的変分法を併用して，2 体間相互作用ポ テンシャルを用いて析出相の弾性定数が母相より硬い場合の相 分解過程について計算機シミュレーションによって研究した。

またこ礼まで報告した雨者の弾性定数が等しい場合の結果に ついても此較検討した。

溶質原子間のポテンシャルは次の 3 種類を用いた.ポテン シャルP1 は溶媒原子のポテンシャル曲線を10\%原子半径の大 きい方へ平行移動したるのである。したがって，析出相と母相 との弾珄定数が等しく，原子半径だけが溶媒原子ょり $10 \%$ 大 きい、ポテンシャルP3 は極小值やその位置はP1 と同様であ るがその形状が異なり，母相上り硬い析出相をるつ。ボテンシ ャルP4 は極小の位置は P1 や P3 と等しいが，極小值が他の ポテンシャルより低く, 曲線の形状も異なる。よって, 母相よ り硬い析出相と他のポテンシャルより強い溶質原子間の結合ニ ネルギーを有する。

これらの溶質原子間のポテンシャルによって得られた結果は 次のと和りである.

（1）異方的な相分解は母相と析出相の弾性定数が等しいP1 のポテンシャルKよる合金に最も明瞭に現れ，P3 のポテンシ ヤルによる母相より硬い析出相を有する合金では異方性が小さ い、また，P3よりさらに硬いP4のポテンシャルでは等方的 な相分解が生じている。

（2）各ポテンンャルで最もエネルギーの低い原子配列状態は ぞのよらな子のかを求めた。 その結果，P4を除いて，P1や P3ではそれぞれ各ポテンシャルKよって相分解した原子配列 状態より P4Kよる異方性のない配列状態の万がエネルギーの 低い状態であることが判明した。

(3) P1 P P3 のポテンシャルKよる合金に招いて，エネル ギー的に高い状態である異方的な組織が生成した理由は，クラ スターが異方的火成長するような原子移動の経路がエネルギー 的低いからである。すすなわち，異方的なクラスターの生成は 弾性エネルギーが最い低い析出物の形状に成長寸るのではな く, 非線形多体効果が関与した相分解の動的過程によるためで
あると結論される.

本シミュレーションの計算は九州大学大型計算機(FACOM VP-200, FACOM M-780/20)和よび北海道大学大型計算機 (HITAC S-820/80)を利用した.

これらの計算機を使用するにあたり九州大学や北海道大学の 大型計算機センターの方々に多くの御教授と御助言をいただき ましたことをここに感謝致します。

また, 本研究の一部は平成 6 年度文部省科学研究費 (一般研 究(C))の補助により行われましたことを付記し，謝意を表し ます。

\section{文献}

(1) J. D. Eshelby: Prog. Solid Mech., 2(1961), 89

(2) A. G. Khachaturyan: Fiz. Tverd. Tela., 8(1966), 2710 (Soviet Phys. Solid St., 8(1967), 2163).

(3) W. C. Johnson: Acta Metall., 32 (1984), 465.

(4) W. C. Johnson and J. W. Cahn: Acta Metall., 32(1984), 1925.

(5) T. Miyazaki, K. Seki, M. Doi and T. Kozakai: Mater. Sci. Eng., $77(1986), 125$.

(6) P. W. Voorhees and W. C. Johnson: Phys. Rev. Lett., $61(1988), 2225$.

(7) K. Kawasaki and Y. Enomoto: Physica, 150A(1988), 463.

(8) J. K. Lee: Metall. Trans., 22A(1991), 1197.

(9) A. Onuki and H. Nishimori: J. Phys. Soc. Jpn., 60 (1991), 1.

（10）竹内 章, 小山敏幸, 宫崎 亨: 日本金属学会誌, $\mathbf{5 7}(1993), 492$.

（11）池田英幸，松田日出彦：日本金属学会誌，56(1992)， 1378; Mater. Trans., JIM, 34(1993), 651.

（12）池田英幸，松田日出彦：日本金属学会誌，54(1990), 1171; Mater. Trans., JIM, 33(1992), 466.

(13) R. A. Johnson and E. Brown: Phys. Rev., 127(1962), 446.

(14) J. R. Beeler, Jr.: Radiation Effects Computer Experiments, Ed. by S. Amelinckx, R. Gevers and J. Nihoul, North-Holland, (1983), 17.

(15) R. A. Johnson: Phys. Rev., 134(1964), A1329.

(16) J. R. Beeler, Jr.: Radiation Effects Computer Experiments, Ed. by S. Amelinckx, R. Gevers and J. Nihoul, North-Holland, (1983), 118.

(17) H. Ikeda and H. Matsuda: Mater. Trans., JIM, 34 (1993), 210.

（18）宮崎 字, 高岸成典, 森 博太郎, 小坂井孝生：日本金 属学会誌, 43 (1979), 826 .

(19) T. Miyazaki, S. Takagishi, H. Mori and T. Kozakai: Acta Metall., 28(1980), 1143.

(20) J. M. Cowley: Phys. Rev., 77(1950), 669.

(21) J. M. Cowley: Phys. Rev., 120(1960), 1648.

(22) J. S. Langer, M. Bar-on and H. D. Miller: Phys. Rev. A11(1975), 1417.

(23) J. W. Cahn.: Trans. Metall. Soc. AIME, 242(1968), 166

（24）小山敏幸, 宮崎 亨: 日本金属学会誌, 53(1989), 643. 